This article was downloaded by: [Australian National University Library]

On: 10 September 2009

Access details: Access Details: [subscription number 907447312]

Publisher Routledge

Informa Ltd Registered in England and Wales Registered Number: 1072954 Registered office: Mortimer House, 37-41 Mortimer Street, London W1T 3JH, UK

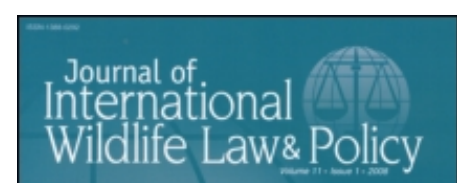

Journal of International Wildlife Law \& Policy

Publication details, including instructions for authors and subscription information:

http://www.informaworld.com/smpp/title content=t713778527

\title{
Australia's National Environmental Legislation: A Response to Early
}

Andrew Macintosh a

a Australian Centre for Environmental Law Canberra, Australia

Online Publication Date: 01 July 2009

To cite this Article Macintosh, Andrew(2009)'Australia's National Environmental Legislation: A Response to Early',Journal of International Wildlife Law \& Policy, 12:3,166 - 179

To link to this Article: DOI: $10.1080 / 13880290903202617$

URL: http://dx.doi.org/10.1080/13880290903202617

\section{PLEASE SCROLL DOWN FOR ARTICLE}

Full terms and conditions of use: http://www.informaworld.com/terms-and-conditions-of-access.pdf

This article may be used for research, teaching and private study purposes. Any substantial or systematic reproduction, re-distribution, re-selling, loan or sub-licensing, systematic supply or distribution in any form to anyone is expressly forbidden.

The publisher does not give any warranty express or implied or make any representation that the contents will be complete or accurate or up to date. The accuracy of any instructions, formulae and drug doses should be independently verified with primary sources. The publisher shall not be liable for any loss, actions, claims, proceedings, demand or costs or damages whatsoever or howsoever caused arising directly or indirectly in connection with or arising out of the use of this material. 


\title{
Australia's National Environmental Legislation: A Response to Early
}

\author{
Andrew Macintosh ${ }^{1}$
}

\section{INTRODUCTION}

In, "Australia's National Environmental Legislation and Human/Wildlife Interactions," published in this journal in 2008 (Vol. 11(2):101-155), Gerard Early describes key elements of the Australian Government's principal piece of environmental legislation, the Environment Protection and Biodiversity Conservation Act 1999 (Cth) (EPBC Act), and analyses its achievements since it commenced in July $2000 .{ }^{2}$ Relying primarily on a small number of case studies, he concludes that the EPBC Act, "clearly demonstrates best practice in environmental assessment."

Early is a Deputy Secretary in the Commonwealth Department of the Environment, Water, Heritage and the Arts. In that position, he heads the branch of the Department that is responsible for the administration of the EPBC Act. His article provides a vivid illustration of the problems that can arise when senior government representatives engage directly in academic discourse. The method Early uses is deficient and the analysis he provides is misleading. Case studies are a useful way of explaining how an environmental assessment regime operates. However, they do not provide a robust basis from which to draw conclusions on their overall effectiveness. This is especially the case when the examples are selected by someone with a vested interest in defending the legislative regime in question. In addition, several of Early's case studies are presented in a misleading manner and his analysis of the structure of the legislation is flawed.

The purposes of this article are to respond to Early's critique of work undertaken by Wilkinson and me in 2005 and highlight some of the more glaring deficiencies in his research. In doing so, the intent is to both correct the

\footnotetext{
${ }^{1}$ Associate Director, Australian National University-Centre for Climate Law and Policy, and Fellow, Australian Centre for Environmental Law Canberra, Australia, 0200. E-mail: macintosha@law.anu.edu.au.

${ }^{2}$ Gerard Early, Australia's National Environmental Legislation and Human/Wildlife Interactions, 11(2) J. INT'L WILDLIFE L. \& PoL'y 101.

${ }^{3} I d$., at 155 .
} 
record and provide readers with a fuller picture of the extent to which the EPBC Act is contributing to ecologically sustainable development in Australia.

\section{RESPONSE TO EARLY'S CRITIQUE}

In 2005, Debra Wilkinson and I conducted a five-year review of the projectbased component of the EPBC Act's environmental impact assessment (EIA) regime. ${ }^{4}$ The research question we sought to answer was whether the EIA regime had been a cost-effective mechanism for furthering the objects of the legislation, which include the protection of the environment (especially matters of national environmental significance (MNES)), the promotion of ecologically sustainable development, the promotion of biodiversity conservation and the protection of heritage.

To answer this question we adopted a two-staged approach. First, we derived an estimate of the costs of administering the EIA regime. Based on official figures and statements made by senior government officials, we found that somewhere between $\mathrm{AU} \$ 55$ million and $\mathrm{AU} \$ 150$ million was spent on administering the EIA regime in its first five years. We did not attempt to estimate compliance costs. The second step was to attempt to judge the regime's environmental effectiveness. This was done by identifying the major threats to Australia's biodiversity and the matters protected under the regime. We then tried to analyse the extent to which the regime was addressing these threats using data on the condition of the relevant aspects of the environment, trends in major environmental threats, and the operation of the regime.

On the basis of the evidence derived from this research method, it was concluded that the EIA regime had failed to significantly improve environmental outcomes and had not been a cost-effective mechanism for tackling Australia's most pressing environmental problems. Three facts were crucial to this finding: (a) the regime captured only a tiny proportion of the actions that posed the greatest threats to the Australian environment; (b) where actions were regulated under the regime, little was achieved beyond what had already occurred under state and territory processes; and (c) the administrative and compliance costs associated with the scheme were substantial. In short, the administrative and compliance costs associated with the regime were not matched by commensurate environmental achievements.

Early critiques the work by Wilkinson and me, stating that:

... their central premise (that you should judge the success of an environmen-

tal assessment regime solely on how many proposals are stopped) demonstrates a

\footnotetext{
${ }^{4}$ Andrew Macintosh and Debra Wilkinson, Environment Protection And Biodiversity Conservation Act: A Five-Year Assessment (2005); Andrew Macintosh \& Debra Wilkinson, EPBC Act-The Case for Reform, 10(1) Australasian J. Natural Res. L. \& Pol'y 139 (2005).
} 
basic misunderstanding of the nature of environmental assessment and out-of-date paradigm that sees conflict as the only means of achieving environmental outcomes. ${ }^{5}$

Wilkinson and I did not suggest that the Commonwealth EIA regime should be judged "solely on how many proposals are stopped." This is a straw-man depiction of our research. The number of refusals and approvals was one piece of evidence that was used to analyse the regime's achievements. In truth, the greatest weakness with the regime over the study period was arguably the lack of referrals from key sectors, not what wasn't rejected. The EIA regime's treatment of land clearing (i.e., deforestation) illustrates this point.

Land clearing for agricultural purposes has arguably posed the greatest threat to the Australian environment in the 2000s. ${ }^{6}$ Approximately 3.5-4.0 million hectares of native vegetation was cleared between 2000 and 2008, making Australia the developed country with the highest rate of deforestation.? Most of this clearing was for agriculture, and a significant proportion of it occurred in regions containing environmental assets that are supposed to be protected under the EPBC Act.

Yet, between July 2000 and 31 July 2008, only 22 agricultural-related land clearing referrals were made under the EIA regime. Fourteen (14) of these referrals were from Queensland - the state that is responsible for the vast majority of the clearing. The total amount of native vegetation clearing associated with these projects was no greater than 12,100 hectares (i.e., less than 0.5 percent of the estimated total). The facts speak for themselves.

Early argues that the Commonwealth, states, territories and local governments agreed, through the Council of Australian Government's (COAG) Heads of Agreement on Commonwealth and State Roles and Responsibilities for the Environment in 1997, that the "conservation of native vegetation" was a matter that should be excluded from the federal EIA regime. ${ }^{8}$ The implication is that the failure to regulate land clearing is not a valid basis for criticising the EPBC Act. This is misleading. The COAG agreement states that the

\footnotetext{
${ }^{5}$ Early, supra note 1 , at 128 .

${ }^{6}$ Australian State of the Environment Committee, Australia State of the Environment 2006 (2006); and Australian State of the Environment Committee, Australia State of the Environment 2001 (2001).

${ }^{7}$ Queensland Department of Natural Resources and Water, Land Cover Change in Queensland 2006-2007: A Statewide Landcover and Trees Study (SLATS) Report (2008); Department of the Environment and Heritage, Greenhouse Gas Emissions From Land Use Change in Australia: Results from the National Carbon Accounting System 1988-2003 (2005); New South Wales Department of Environment and Climate Change, NSW Woody Vegetation Change: 2006 to 2007 Report (2008); New South Wales Audit Office, Regulating the Clearing of Native Vegetation (2006); Department of Climate Change, Australian Greenhouse Emissions Information System (AGEIS): Emission results for 1990-2006, <http://www.climatechange.gov.au/inventory/index.html> (12 April 2009); and United Nations Framework Convention on Climate Change Secretariat, Greenhouse Gas Inventory Data, $<$ http://unfccc.int/ghg_data/items/3800.php $>$ (accessed 5 January 2009).

${ }^{8}$ Early, supra note 1 , at 130 .
} 
Commonwealth's environmental assessment and approval processes should only be triggered by proposals that may have a significant impact on one of the seven MNES. ${ }^{9}$ Included on the list of MNES are "nationally endangered or vulnerable species and communities." ${ }^{10}$ Given this, and the corresponding provisions in the EPBC Act, ${ }^{11}$ land clearing should have been regulated under the EPBC Act to the extent that it has contributed to the pressure on Australia's threatened species and ecological communities. This has not occurred.

Moreover, the reference to the "conservation of native vegetation" in the COAG agreement is limited and was not intended to exclude all land clearing from the scope of the federal EIA regime. The relevant provision merely provides that the Commonwealth has an interest in "taking programme and co-operative measures with the States and other interested parties to conserve and manage native vegetation and fauna."'12

In addition to the lack of referrals from key sectors, Wilkinson and I found there were problems with the extent to which the Commonwealth process was adding value. Approvals were given without conditions, some conditions were of dubious environmental merit, some outcomes duplicated those from state processes, some conditions were unenforceable and there was a lack of monitoring of approved projects. Our concerns were not simply that nothing was being rejected; it was that the regime was not regulating key processes or adding significant value.

The findings that Wilkinson and I reached were largely consistent with those from the Australian National Audit Office's report in 2007. ${ }^{13}$ The Audit report found "there is likely to be a materially significant number of missed referrals each year." ${ }^{14}$ It also concluded that the regime was not capturing land clearing actions and that there were gaping holes in the monitoring and enforcement systems.

\section{EARLY'S CASE STUDIES}

There are a little over a dozen case studies in Early's article that relate to the project-based component of the EIA regime. I will use four of these to highlight some of the problems with Early's analysis: the expansion of the Warkworth Coal Mine in New South Wales; ${ }^{15}$ the expansion of the Koolyanobbing iron ore

\footnotetext{
${ }^{9}$ Council of Australian Governments, Heads of Agreement on Commonwealth and State Roles and Responsibilities for the Environment (1997), Article 4 And Attachment 1, Part I.

${ }^{10}$ Id., Article 4 and Attachment 1, Part I, clause 4.

${ }^{11}$ Environment Protection and Biodiversity Conservation Act 1999 (Cth), ss18 and 18A.

${ }^{12}$ Council of Australian Governments, supra note 8, Attachment 1, Part II, clause 27.

${ }^{13}$ Commonwealth Auditor-General, The Conservation and Protection of National Threatened Species and Ecological Communities, Audit Report No. 31 (2007).

${ }^{14} \mathrm{Id}$., at 130 .

${ }^{15}$ Details of all referrals under the EPBC Act are available on the Department's public notices website (http://www.environment.gov.au/epbc/notices/index.html) (accessed 12 December 2008). The Warkworth Coal Mine's EPBC Reference Number is 2002/629.
} 
mine in Western Australia ${ }^{16}$ a proposal by Iluka Resources Ltd. to establish a mineral sands mine in the Cataby region north of Perth (Western Australia), ${ }^{17}$ and the Gwydir wetlands case (which is more commonly referred to as the 'Greentree Case'). ${ }^{18}$

Prior to looking at these case studies, it is necessary to comment on the relationship between federal and state processes. State and territory planning and environment laws are the primary policy mechanism for regulating land use, development, and pollution in Australia. ${ }^{19}$ The EPBC Act's EIA regime is a relative newcomer that has effectively been tacked onto the state systems. As it is confined to MNES, the EPBC Act also has a relative narrow reach. Where a project undertaken in a state triggers the federal EIA regime because of potential impacts on the MNES, it will usually also require one or more state approvals. The operation of the state processes often reduces the scope for the EPBC Act to generate tangible environmental benefits. Where state processes generate outcomes that are consistent with federal policy, there is little the EPBC Act can do.

Due to the existence of the state regimes, a central theme of any analysis on the cost-effectiveness of the EPBC Act should be: has it added value to the state processes? If the EIA regime is unable to produce noticeable benefits above and beyond those associated with state processes, it would be more efficient to redeploy the resources used in its administration and compliance to other areas.

\subsection{Warkworth Coal Mine}

The Warkworth Coal Mine is an open cut mine located near Singleton in the Hunter Valley in New South Wales. It has operated since 1981 and, at the time of the referral, had an approved output of seven million tonnes per annum of saleable coal (roughly 10 million tonnes of run-of-mine coal). The referral under the EPBC Act in 2002 involved extending the existing pits at the mine so as to increase output to 18 million tonnes per annum of run-of-mine coal.

The development was approved under the EPBC Act in February 2004 and several conditions were imposed, the most important of which concerned so-called "Green Offsets." These conditions required the proponent to retain and manage 1,092 hectares of existing native vegetation in exchange for the clearance of 258 hectares of foraging habitat for the regent honeyeater (Xanthomyza phrygia), a listed threatened species. Early comments

\footnotetext{
${ }^{16}$ EPBC Reference No. 2001/174.

${ }^{17}$ EPBC Reference No. 2005/2001.

${ }^{18}$ Minister for the Environment and Heritage v. Greentree (No. 2) [2004] FCA 741; and Greentree v. Minister for the Environment and Heritage [2005] FCAFC 128.

${ }^{19}$ From 2010, the regulation of greenhouse gas emissions will be undertaken primarily through the Federal Government's proposed Carbon Pollution Reduction Scheme, which is an emissions trading scheme.
} 
that " $[t]$ his project demonstrates how an offset can contribute positively when human/wildlife interactions inevitably lead to some destruction of wildlife," ${ }^{20}$ implying that the EPBC Act was responsible for this outcome.

While the environmental merit of offset conditions such as these is debatable (i.e., there was still a net loss of native vegetation), the EPBC Act's contribution to the on-ground outcome was negligible. The Green Offset strategy for the extension was developed in collaboration with the NSW Government in the early 2000s. ${ }^{21}$ The project was subsequently approved by the NSW Planning Minister in May 2003 and subject to a series of offset conditions that were very similar to those imposed under the EPBC Act in $2004 .{ }^{22}$ Early dressed this case study up as an example of how the EPBC Act has achieved real benefits. In reality, all the EPBC Act did was duplicate state processes without adding any significant environmental value.

\subsection{Koolyanobbing Iron Ore Project}

The Koolyanobbing iron ore project involved a similar outcome. The development involved the construction of up to nine open cut iron ore mines to exploit new deposits at Mt. Jackson, Windarling, and Bungalbin in Western Australia. The most environmentally controversial aspect of the project was that it required the displacement or destruction of a large number of Tetratheca paynterae, a threatened plant species.

Due to the nature of the impacts, the proposal was subject to a protracted state assessment process. The Western Australian Environmental Protection Authority originally recommended that the project not be allowed to proceed. ${ }^{23}$ This recommendation was reversed on appeal. ${ }^{24}$ The Appeals Convenor found that the project should be allowed to proceed provided conditions were imposed to reduce the impacts on the Tetratheca paynterae population. These conditions included that mining be restricted "such that no more than 30 percent of the population of Tetratheca paynterae is initially directly impacted by mining activities" and that a further 20 percent be allowed to be directly affected if a "Research and Management Plan and a Recovery Plan are completed which demonstrate that the remaining population will be viable."25 The Western Australian Government officially approved the project in June 2003,

\footnotetext{
${ }^{20}$ Early, supra note 1, at 141 .

${ }^{21}$ Sarah Fish, David Snashall, and James Streater, OfFSETting Environmental ImPacts to Facilitate Mining (2004).

${ }^{22}$ New South Wales Development Approval (DA) 300-9-2002i; Rohan Taylor (NSW Department of Planning) (pers. comms. 8 January 2009); and Coal \& Allied, NSW Premier Announces Extension to Warkworth Mine, Media Release, 29 May 2003.

${ }^{23}$ Western Australian Environmental Protection Authority, Koolyanobbing Iron Ore Expansion: Portman IRON ORE LTD. (2002).

${ }^{24}$ Darren Walsh, Appeals Report: Proposed Koolyanobbing Iron Ore Expansion (2003).

${ }^{25} I d$., at 15 .
} 
subject to conditions that reflected these recommendations. ${ }^{26}$ Three months later, the project was approved under the EPBC Act.

The EPBC Act conditions largely mirrored the relevant state conditions. The works had to be confined to particular areas and management plans had to be prepared to minimise impacts on the threatened species. Just as in the state approval, the removal of the Tetratheca paynterae population was conditioned in two stages: 30 percent in the first stage and a further 20 percent that was contingent on the Minister approving a report demonstrating that "the remaining population has not been significantly impacted upon and that actions in the Research and Management Plan and the Recovery Plan are being implemented to the satisfaction of the Minister." ${ }^{27}$

The federal EIA regime added little from an environmental perspective to the state outcome. Early acknowledges there were similarities between the Commonwealth and state conditions, but argues that the EPBC Act conditions were "significantly more stringent" than those imposed by the Western Australian Government. ${ }^{28}$ This is not reflected in the approval documentation, nor is it the view of the proponent, Portman Iron Ore Ltd. In a research interview conducted in early 2009, the General Manager of Portman Iron Ore Ltd., Richard Mehan, stated that the EPBC Act conditions were similar to those imposed by the state government and the federal process did not improve the environmental outcomes from the project. ${ }^{29}$

\subsection{Iluka Resources Ltd. Mineral Sands Proposal}

The Iluka Resources Ltd. mineral sands proposal involves a 650 hectare site north of Perth, of which 124 hectares contains native vegetation. The primary EPBC Act issue relates to the loss of Carnaby's black cockatoo habitat. Carnaby's black cockatoo (Calyptorhynchus latirostris) is a nationally listed endangered species. Prior to referring the project under the EPBC Act, and in consultation with state government agencies and other stakeholders, the proponent prepared a management plan that included a range of mitigation and offset measures to deal with the potential impacts on the cockatoo.

After the management plans for the cockatoo had been settled, the proponent referred the project under the EPBC Act. On 17 March 2005, a month after the referral was made, the Federal Minister found that the project did not require formal assessment and approval under the EPBC Act if the mitigation and offset measures were implemented. Thirteen months later (April

\footnotetext{
${ }^{26}$ Western Australian Minister for the Environment, and Heritage, Statement That a Proposal May Be Implemented, Koolyanobbing Iron Ore Expansion-Windarling Range and Mt. Jackson, Shire of Yilgarn, Statement No. 000627, 3 June 2003. See also Judy Edwards, Minister Determines Appeals on Portman Mine Expansion, Media Release, 1 April 2003.

${ }^{27}$ Approval Instrument for EPBC Reference No. 2001/174, at 3.

${ }^{28}$ Early, supra note 1, at 139.

${ }^{29}$ Richard Mehan, Portman Ire Ore Ltd., pers. comms. (8 January 2009).
} 
2006), formal approval for the project was granted by the Western Australian Government. ${ }^{30}$ The state conditions require the management plan and associated mitigation and offset measures be implemented.

Although the EPBC Act approval preceded the state approval, its contribution to the outcome appears to have been negligible. The available approval documentation suggests the state process and initiative of the proponent were the major drivers of the outcome. To confirm this, an interview was conducted with Lisa McGrath, the Environmental Regulatory Officer at Iluka Resources Ltd., who was responsible for the handling of the referral. ${ }^{31}$ She stated that the EPBC Act process did not add anything to what was achieved under the state process.

\subsection{Greentree Case}

The Greentree Case involved a civil proceeding against a wheat farmer and an associated company who were found to be responsible for completely clearing 100 hectares of an ephemeral Ramsar-listed wetland on a property known as Windella near Moree in northern New South Wales. ${ }^{32}$ The Federal Court fined the farmer and the company involved a total of $\$ 450,000$ and ordered them to carry out restoration work on the wetland.

As described by Early, the Greentree case appears to provide evidence of the Commonwealth's resolve to enforce the EIA regime and raise environmental standards. The background to the proceedings presents a more complex picture of the case. The Commonwealth was first made aware of the clearing on Windella in early September 2002 when an employee of The Wilderness Society (a large environmental NGO) sent aerial photographs of what turned out to be preliminary clearing on the property to the Commonwealth Environment Department. On 30 September 2002, the Department sent a letter to the defendants about the alleged clearing and asked if it could inspect the property. The defendants refused. The Department then obtained a warrant to inspect the property.

On 15 October 2002, a site inspection was conducted on the property, which found "that approximately 20 percent of the Windella Ramsar site in the north-eastern portion had been cleared of all ground cover" and that dredging had occurred within the site. ${ }^{33}$ Despite this finding, the Government did not commence legal proceedings against the defendants, preferring to attempt to negotiate an outcome. These negotiations dragged on for over six months,

\footnotetext{
${ }^{30}$ Western Australian Minister for the Environment, Statement That a Proposal May Be Implemented,Cataby Mineral Sands Project-Cataby, Shire of Dandaragan, Statement No. 000720, 18 April 2006.

${ }^{31}$ Lisa McGrath, Iluka Resources Ltd., pers. comms. (8 January 2009).

${ }^{32}$ Minister for the Environment and Heritage v. Greentree (No.2) [2004] FCA 741; and Greentree v. Minister for the Environment and Heritage [2005] FCAFC 128.

${ }^{33}$ Minister for the Environment \& Heritage v. Greentree (No 2) [2004] FCA 741 at 96.
} 
during which time the defendants continued to clear the property. ${ }^{34}$ When the Department subsequently inspected the site in late July 2003, they found the entire site had been cleared of all ground cover and that the soil had been ploughed. Upon discovering this, the civil proceedings were commenced.

There are a number of aspects of this case that are curious. Why didn't the Commonwealth initiate enforcement proceedings in 2002 when it first became aware of the clearing? One of the defendants in the case, Ronald Greentree, has a record of clearing native vegetation and has been involved in a number of legal actions concerning land clearing in New South Wales. ${ }^{35}$ Due to this, the Commonwealth should have been on notice of the risk the property would be cleared if it delayed enforcement proceedings. At the very least, it could have sought an injunction (like the one it later obtained) to prevent further clearing until the negotiations had been completed. ${ }^{36}$

Why didn't the Commonwealth take criminal proceedings against the defendants? The case involved a blatant breach of the legislation, which was aggravated by the defendants' refusal to cooperate. If criminal sanctions are not warranted in these circumstances, when are they?

The case was important. However, it was hardly a "win" for the environment. If anything, it highlighted how deficient and timid the monitoring and enforcement efforts have been. There has been evidence of widespread noncompliance with the regime since it commenced. Despite this, the Greentree case is the only successful prosecution that has been carried out under the EIA provisions of the legislation. Moreover, the Commonwealth has failed to monitor compliance, including with the conditions imposed on projects under the regime, and done little to raise awareness of the legislative requirements. ${ }^{37}$

\subsection{Discussion}

The fact Early selected these four cases to illustrate the benefits of the EPBC Act speaks volumes about what its overall contribution has been. Consistent with the findings of the research I conducted with Wilkinson in $2005,{ }^{38}$ the projects Early uses are examples of where the EPBC Act has added little, if anything, to state processes. They do not provide evidence to support the view that the EPBC Act is a cost-effective environmental policy instrument.

\footnotetext{
${ }^{34}$ Minister for the Environment and Heritage v. Greentree (No 2) [2004] FCA 741, at 43 and 93-108.

${ }^{35}$ See Director-General of the Department of Land and Water Conservation v. Greentree [1998] NSWLEC 30; Director-General of the Department of Land and Water Conservation v. Greentree [2001] NSWLEC 159; Greentree v. Director-General of the Department of Land and Water Conservation [2002] NSWLEC 53; Greentree v. Director-General of the Department of Land and Water Conservation [2002] NSWLEC 93; Director-General of the Department of Land and Water Conservation v. Greentree [2002] NSWLEC 102; and Director-General Department of Land and Water Conservation v. Greentree [2004] NSWLEC 584.

${ }^{36}$ Minister for the Environment and Heritage v. Greentree [2003] FCA 857.

${ }^{37}$ Commonwealth Auditor-General, supra note 12.

${ }^{38}$ Macintosh and Wilkinson, supra note 3.
} 
Similarly, the Greentree Case is not an example of a positive environmental outcome, nor does it demonstrate the resolve of the Federal Government to lift environmental standards. More than anything, it highlights the weaknesses in enforcement that have undermined the effectiveness of the EIA regime.

\section{ADDITIONAL WEAKNESSES IN EARLY'S ANALYSIS}

There are a number of other aspects of Early's article that are deficient or misleading. Three stand out: his description of the threatened species and ecological communities listing processes; his failure to explain the problems that have plagued the federal heritage regime; and the absence of discussion on the lopsided assessment and approval process.

\subsection{Threatened Species and Ecological Communities}

In his upbeat description of the listing processes for threatened species and ecological communities, Early does not analyse how the process does not reflect best practice or how it has been manipulated to limit the scope of the Commonwealth's involvement in environmental regulation. Ideally, lists of threatened species and communities should be maintained by an independent scientific body, which makes listing decisions on a purely scientific basis. A scientifically rigorous listing process ensures there is a credible and comprehensive list of threatened species and communities. Decisions about the protection of these assets, and trade-offs among economic, social, and environmental objectives, can then be made through planning and approval processes.

When the EPBC Act was first introduced, the statutory listing processes for threatened species and ecological communities were reasonably good. Nominations could be made by members of the public. The Threatened Species Scientific Committee (TSSC) was required to evaluate nominations against scientific criteria and provide advice to the Minister. After receiving advice from the TSSC, the Minister was required to make a listing decision within a defined timeframe. In making a listing decision, the Minister was not allowed to consider any matter that did not relate to the "survival" of the species or ecologically community in question. The Minister was also under a statutory obligation to "take all reasonably practical steps" to keep the lists of threatened species and ecological communities in an up-to-date condition.

This reasonably robust listing process proved politically difficult for the Commonwealth. As species and ecological communities are listed, the scope of the EIA regime expands. This phenomenon caused consternation among certain sectors, particularly farmers and fishers. The Government's response was three-fold. Firstly, it simply refused to include species and ecological communities on the lists. The statistics on ecological communities reflect 
this. In 2002, the National Land and Water Resources audit identified 2,891 threatened ecosystems and other ecological communities in Australia. ${ }^{39}$ At the time of writing, the Commonwealth had listed only 44, seven of which were added in 2008 and 2009..$^{40}$

Other examples include the treatment of the Queensland lungfish and commercial fish species-only one commercial fish species has been listed (orange roughy), despite evidence a number meet the listing criteria. Early puts the problems with listings down to "the magnitude of the tasks." ${ }^{41}$ While resourcing has been an issue, other factors have clearly been influential.

Secondly, the Government introduced a policy of excluding "significantly degraded (low condition) areas" from listed ecological communities for the purposes of the Act. ${ }^{42}$ This administrative approach is inconsistent with the legislation. The Act defines an ecological community as "the extent in nature in the Australian jurisdiction of an assemblage of native species that ... inhabits a particular area in nature. ${ }^{\prime 43}$ To meet the grade for listing, the community must also satisfy additional criteria set out in the regulations related to the decline in its geographic distribution and ecological integrity. Nowhere in the legislation or regulations is there an explicit power to exclude part of an ecological community from the reach of the EIA process on the grounds it is degraded. In fact, one of the criteria for listing is that there has been a reduction in the integrity of the community across most of its geographic distribution as indicated by degradation of the community or disruption of important community processes. ${ }^{44}$ Seemingly, a community can now meet the statutory criteria for listing on the basis of degradation, but then be excluded from the listed community by administrative fiat because of the degradation.

In adopting this approach, the Commonwealth has repeated the legal error it committed in the Flying Fox Guidelines Case by purporting to amend

\footnotetext{
${ }^{39}$ Paul Sattler and Colin Creighton, Australian Terrestrial Biodiversity Assessment 2002 (2002).

${ }^{40}$ Some may argue that the refusal or failure to list ecological communities was a product of the fact that a number of nominated communities did not fit within the TSSC's assessment framework. The framework is based on the National Vegetation Information System (NVIS) and is intended to ensure a consistent and verifiable approach to ecological community identification and evaluation. While this approach may have policy merit, the rejection of nominations that did not fit within the framework was inconsistent with the legislative process. The role of the TSSC is to determine whether nominated communities meet the legislative definition of a community and the conservation status criteria contained in the regulations. It cannot unilaterally determine the scope of its powers without regard to the provisions in the Act. One may also question whether the TSSC was acting in a manner consistent with its legislative functions when it provided advice that was inconsistent with the legislation and advocated for legislative reform. Irrespective of the legality of the TSSC's approach, the rejection of nominated communities provides a very partial explanation for the low number of listings. Even if the NVIS framework is accepted, many more ecological communities should have been included on the list.

${ }^{41}$ Early, supra note 1 , at 130 .

${ }^{42}$ Department of the Environment and Heritage, Ecological Communities and the EPBC Act: A New Approach To Listing Ecological Communities (2006).

${ }^{43}$ Environment Protection and Biodiversity Conservation Act, s528.

${ }^{44}$ Environment Protection and Biodiversity Conservation Regulations 2000, r7.02.
} 
the legislation via a policy pronouncement. ${ }^{45}$ This policy also potentially adds to the uncertainty associated with the EIA regime by creating further ambiguity about when it applies to ecological communities. Proponents have to identify whether their action might affect a listed ecological community, which is often a difficult task. If there is an ecological community that may be affected, a second question arises as to whether it is degraded. What constitutes degraded for these purposes is unclear. In the two page policy document published by the Department on this issue, the front page refers to "significantly degraded" areas being excluded, whereas the back page simply states:

\begin{abstract}
Areas in a degraded condition will not be included as part of a listed ecological community. ${ }^{46}$
\end{abstract}

Eleven lines later on the same page, the policy reiterates:

Landholders will not be required to seek approval under the EPBC Act for actions occurring on land containing degraded examples of a listed ecological community. ${ }^{47}$

Interestingly, the policy document emphasises that landholders will still be eligible for grants to help improve the condition of degraded areas. No regulation, just subsidies. The scheme appears to be designed to appease farm lobby groups by reassuring farmers that they do not have to comply with the EIA process, while guaranteeing that they still have access to government grants.

The third limb of the Government's response to threatened species and communities was to amend the legislation in 2006 to ensure the Minister and the TSSC had complete control over what is assessed and included on the lists. Public nominations can still be made, but the TSSC and the Minister control what gets assessed. The listing processes now have a political gatekeeper. In addition, the statutory obligation for the Minister to ensure the lists are maintained in an up-to-date condition was removed, along with the strict statutory timelines on assessments and listing decisions.

Early describes the new process for ecological communities that emerged from the legislative changes and policy shift as "scientifically credible, objective, repeatable, practical, easily understood by the general community, and applicable within Australia's natural resource management framework." ${ }^{48}$ The facts paint a different picture. The listing processes for species and ecological communities are far from best practice. Changes were warranted to these

\footnotetext{
${ }^{45}$ Humane Society International Inc. v. Minister for the Environment and Heritage [2003] FCA 64. See Early, supra note 1, at 133.

${ }^{46}$ Department of the Environment and Heritage, supra note 41.

${ }^{47}$ Id.

${ }^{48}$ Early, supra note 1, at 147.
} 
processes to improve their strategic direction and account for administrative constraints. However, those that were made took the regime backwards.

\title{
4.2 Heritage Listing Process
}

The same issues that have plagued the threatened species and ecological communities listing processes have been evident in the federal heritage regime. Prior to 2004, there was a Register of the National Estate that was maintained by the Australian Heritage Commission under the Australian Heritage Commission Act 1975 (Cth). The listing process for the Register was independent and heritage-based, a fact that frequently caused problems for the Federal Government. In 2004, the old regime was abolished and a new regime was created within the EPBC Act. At the core of the new regime are the lists of National and Commonwealth heritage places.

There are a number of aspects of the new regime that are commendable. The listing processes are not among them. In a retrograde step, the new regime stripped the listing responsibilities from the Australian Heritage Commission (which was renamed the Australian Heritage Council) and handed them to the Minister. The Council is now an advisory body only. The result has been a politicized heritage listing process. There have also been problems with the way the EIA regime is applied to heritage assets. A senior figure in the Australian heritage community (who asked to remain anonymous for fear of reprisals) had this to say about the new heritage regime:

\begin{abstract}
Heritage listings have been too slow and often politicised, heritage protection has in reality taken a giant step backwards .... . In addition the Australian Heritage Council is a timid advocate subject to the controlling-hand of the Department.

Regarding protection, I believe the Commonwealth is the only Australian jurisdiction which uses broadscale environment impact assessment processes as a primary protection tool for historic heritage. Every other jurisdiction has specific heritage protection legislation. The decades of experience with heritage protection have been lost in favour of the blunt instrument which is the EPBC Act .... While there has been no authoritative, independent, expert review of heritage protection under the Act, industry sources are dismayed with the Act. They believe it is the wrong model to follow, which is in the hands of people who do not understand heritage. ${ }^{49}$
\end{abstract}

Early's article is silent on these issues.

\subsection{Lopsided Assessment and Approval Process}

A peculiar aspect of the EPBC Act's EIA regime is that its assessment and approval processes are lopsided. Assessments focus only on the MNES that triggered the project's inclusion within the EPBC Act process. Similarly, when

\footnotetext{
${ }^{49}$ [Name withheld], pers. comm. (7 May 2008).
} 
making approval decisions, the Minister is required to have regard to economic and social matters related to the action, but the relevant environmental issues are confined to the impacts associated with the MNES that triggered the approval requirement. For example, if the impacts associated with a project included air pollution and the clearing of a population of threatened plant species, the EIA process would look only at the impacts on the plant species. The air pollution would be irrelevant.

The effect of this decision making framework is to create a process for the weighing of competing interests, similar to a cost-benefit analysis, where a substantial section of the environmental equation is often excluded. This creates a structural bias against environmental interests. Early is well aware of this issue, but chose not to explore it in detail in his article. Such a lopsided process is the antithesis of best practice environmental assessment.

\section{CONCLUSION}

Early's article on the EPBC Act contains some useful descriptive material. However, his analysis is flawed. To some extent, this is understandable-he is responsible for the administration of the legislation. In that capacity, he has a responsibility to execute government policy. He is also likely to have a personal stake in the success of the regime, or at least the perception of success. While the motive for the article is understandable, this does not provide a justification for the content. Opinions may differ on whether the regime has been a cost-effective policy instrument. This is the nature of environmental assessment processes - people have different values and they will influence their perceptions on the merits of the outcomes from the process. However, Early's method is deficient and his analysis is distorted and misleading. 